\title{
MODIFIKASI DAN KARAKTERISASI PATI BATANG KELAPA SAWIT SECARA HIDROLISIS SEBAGAI BAHAN BAKU BIOPLASTIK
}

\author{
Agustina Arianita Cahyaningtyas ${ }^{1}$, Rahyani Ermawati ${ }^{1}$, Guntarti Supeni ${ }^{1}$, Firda A. \\ Syamani $^{2}$, Nanang Masruchin ${ }^{2}$, Wida B. Kusumaningrum ${ }^{2}$, Dwi A. Pramasari ${ }^{2}$, \\ Teguh Darmawan ${ }^{2}$, Ismadi ${ }^{2}$, Eko S. Wibowo ${ }^{2}$, Dimas Triwibowo ${ }^{2}$, dan Sukma S. \\ Kusumah $^{2}$ \\ ${ }^{1}$ Badan Penelitian dan Pengembangan Industri, Kementerian Perindustrian, \\ Jl. Gatot Subroto Kav. 52-53 Jakarta Selatan, Daerah Khusus Ibukota Jakarta, Indonesia 12950 \\ ${ }^{2}$ Pusat Penelitian Biomaterial, Lembaga IImu Pengetahuan Indonesia ( LIPI), Jalan Raya Bogor Km. \\ 46, Cibinong, Jawa Barat, Indonesia 16911 \\ E-mail : agustinaarianita@gmail.com
}

Received : 18 Januari 2019; revised : 15 Maret 2019; accepted : 24 April 2019

\begin{abstract}
ABSTRAK
MODIFIKASI DAN KARAKTERISASI PATI BATANG KELAPA SAWIT SECARA HIDROLISIS SEBAGAI BAHAN BAKU BIOPLASTIK. Batang kelapa sawit mengandung kadar pati yang tinggi sehingga memiliki potensi digunakan sebagai bahan baku bioplastik. Kadar amilosa dalam pati batang kelapa sawit dapat dinaikkan melalui proses modifikasi dengan pelarut asetat. Tujuan dari penelitian ini adalah untuk meningkatkan sifat kimia (kadar amilosa) dan termal pati batang kelapa sawit melalui proses modifikasi sebagai bahan baku bioplastik. Dalam penelitian ini, pati batang kelapa sawit diperoleh melalui proses ekstraksi. Modifikasi pati batang kelapa sawit dilakukan dengan menggunakan larutan asetat $(\mathrm{CH} 3 \mathrm{COOH}+\mathrm{CH} 3 \mathrm{COONa}) \quad \mathrm{pH} 7$. Karakterisasi pati batang sawit dilakukan dengan melihat komposisi kimia (kadar air, abu, protein, lemak, amilosa, dan amilopektin), analisis gugus, dan karakteristik termal. Hasil karakterisasi komposisi kimia pati batang kelapa sawit termodifikasi menunjukkan peningkatan kadar amilosa dari $26 \%$ menjadi $29 \%$. Kandungan rantai lurus dalam amilosa yang semakin banyak akan meningkatkan kestabilan pati. Hasil Thermal Gravimetry Analysis (TGA) menunjukkan bahwa pati batang kelapa sawit termodifikasi lebih cepat terdegradasi dibandingkan pati batang kelapa sawit tidak termodifikasi/alami, sedangkan data Derivative Thermal Gravimetry (DTG) dan analisis Differential Scanning Calorimetry (DSC) menunjukkan pengurangan massa pati batang kelapa sawit termodifikasi lebih kecil dari pati batang kelapa sawit tidak termodifikasi/alami serta pati batang kelapa sawit termodifikasi mempunyai $T g$ (Gelatinization Temperature) yang lebih rendah. Hasil penelitian pati batang kelapa sawit termodifikasi ini diharapkan dapat diaplikasikan sebagai bahan baku bioplastik yang ramah lingkungan.
\end{abstract}

Kata kunci : Pati batang kelapa sawit, Pati batang kelapa sawit termodifikasi, Bioplastik

\section{ABSTRACT}

MODIFICATION AND CHARACTERIZATION OF OIL PALM TRUNKS STARCH BY HYDROLYSIS AS BIOPLASTIC RAW MATERIAL. The oil palm trunk has a high starch content and thus has the potential to be used as a bioplastic material. Amylose content in the oil palm starch can be increased through a modification process with acetate solvent. The purpose of this study is to improve the chemical (amylose content) and thermal characteristics of modified oil palm starch as a bioplastic raw material. In this work, the oil palm starch was obtained through the extraction process. Modification of oil palm starch was carried out using acetate solution $(\mathrm{CH} 3 \mathrm{COOH}+\mathrm{CH} 3 \mathrm{COONa}) \mathrm{pH}$ 7. Characterization of the oil palm starch included chemical composition (moisture content, ash, protein, fat, amylose, and amylopectin), functional groups, and thermal characteristics. The results showed that amylose content in the modified oil palm starch increased from $26 \%$ to $29 \%$. The presence of straight chains in amylose would increase starch stability. Thermal Gravimetry Analysis (TGA) results showed that the modified oil palm starch would degraded faster than that of non-modified/natural oil palm starch, whereas Derivative Thermal Gravimetry (DTG) and analisis Differential Scanning Calorimetry (DSC) data also showed a smaller mass reduction of modified oil palm starch than that of non-modified / natural oil palm starch. Further, the modified oil palm starch has a lower $\mathrm{Tg}$ (Gelatinization Temperature). The results of this could be applied as a raw material for environmentally friendly bioplastics.

Keywords : Oil palm starch, Modified oil palm starch, Bioplastic 


\section{PENDAHULUAN}

Penggunaan plastik sebagai kemasan saat ini semakin meningkat, mulai dari elektronik, alat rumah tangga, makanan, dan minuman menggunakan plastik sebagai pengemas. Plastik memiliki kelebihan yaitu ringan, mudah dibentuk, kuat, dan harga yang terjangkau. Namun plastik memiliki kekurangan sulit terdegradasi sehingga berdampak negatif dan mencemari lingkungan. Plastik yang sebagian besar berasal dari polimer sintetis akan terdegradasi puluhan bahkan ratusan tahun dan jika dibakar emisi karbon yang dihasilkan juga dapat mencemari lingkungan (Kamsiati, Herawati, and Purwani 2017).

Bioplastik merupakan plastik yang ramah lingkungan dan mudah terurai secara alami. Bioplastik terbuat dari bahan alam yang dapat diperbarui atau polimer alam seperti dari pati, serat alam, selulosa, kolagen, kasein, protein atau lipid yang terdapat dalam hewan, lemak, kitosan dan bahan alam lainnya. Bioplastik dapat digunakan seperti halnya plastik konvensional namun akan mudah terdegradasi oleh mikroorganisme setelah pemakaian dan dibuang di lingkungan. Penggunaan bioplastik ini dapat dijadikan sebagai salah satu alternatif untuk mengurangi plastik konvensional yang terbuat dari petroleum, gas alam, dan batu bara (Saputro and Ovita 2017); (Kamsiati, Herawati, and Purwani 2017).

Salah satu bahan bioplastik adalah pati. Pati alami dalam industri pangan maupun non pangan memerlukan modifikasi sifat dengan menggunakan teknologi di bidang pengolahan pati. Modifikasi pati menyebabkan perubahan karakteristik fisika, kimia, maupun enzimatis pati. Tujuan modifikasi pati adalah untuk menstabilkan granula pati selama proses. Modifikasi pati secara fisika antara lain dengan panas, radiasi, gesekan, dan pembekuan. Sedangkan modifikasi secara kimia antara lain hidrolisis menggunakan enzim, modifikasi menggunakan asam, oksidasi, eterefikasio, esterifikasi, dan ikatan silang (Zulaidah 2012); (Erika 2010); (Korma et al. 2016); (Onyango 2016). Pati sebagian besar tersimpan dalam umbi, batang, buah, dan biji. Komponen utama granula pati yaitu amilosa (15\% hingga $30 \%$ ), amilopektin (70\% sampai dengan $85 \%$ ), dan material lain seperti protein dan lemak (5\% sampai dengan 10\%). Amilosa merupakan polimer rantai lurus, sedangkan amilopektin merupakan polimer rantai bercabang. Granula pati berukuran $1 \mu \mathrm{m}$ sampai dengan $100 \mu \mathrm{m}$. Struktur dan jenis material sumber pati (bentuk, ukuran, distribusi ukuran, dan kristalinitas granul) tergantung pada sifat botani sumber pati.

Penelitian pembuatan bioplastik berbahan baku pati telah banyak dilakukan. Bioplastik berbahan baku pati memiliki kelemahan pada sifat fisik dan barriernya, sehingga banyak penelitian bioplastik berbahan baku pati yang dicampur dengan bahan aditif lain supaya dapat memperbaiki kelemahan sifat pati. Penelitian bioplastik berbahan baku pati yang telah dilakukan antara lain pembuatan bioplastik dari pati sagu, pati ganyong, pati ubi jalar, pati biji durian, pati singkong, pati biji nangka, pati sorgum, dan pati jagung (Silviana and Rahayu 2017); (Saputro and Ovita 2017); (Aripin, Saing, and Kustiyah 2017); (Cornelia et al. 2013), (Suryanto et al. 2016); (Purbasari, Ariani, and Mediani 2014); (Darni and Utami 2010); (Coniwanti, Laila, and Alfira 2014). Selain ditambah dengan bahan aditif lain, untuk memperbaiki sifat dan memenuhi karakteristik yang diperlukan telah dilakukan pula penelitian bioplastik dari pati termodifikasi. Penelitian bioplastik dari pati termodifikasi antara lain bioplastik dari pati tapioka termodifikasi dan pati sagu termodifikasi, (Supeni, Cahyaningtyas, and Fitrina 2015); (Harsojuwono, Arnata, and Mulyani 2017); (Yuliasih and Sunarti 2014).

Limbah batang kelapa sawit saat ini penanganannya hanya dibakar yang dapat mencemari udara, selain itu membiarkan limbah batang kelapa sawit hasil peremajaan menimbulkan masalah bagi tanaman kelapa sawit baru yaitu menjadi sarang serangga, hama dan tikus. Pati batang kelapa sawit terdapat pada bagian yang mengandung persentase lignin yang tinggi yaitu sel parenkim dari jaringan vascular kasar. Namun, kandungan amilosa pati kelapa sawit $(96 \%)$ lebih kecil dibanding dengan pati sagu (97,85\%) dan tapioka (96,99\%) (Ridwansyah et al. 2010). Menurut Kamsiati, Herawati, and Purwani 2017, amilosa yang tinggi akan membentuk kristal yang menghasilkan sifat mekanis bioplastik yang lebih kuat dibandingkan amilopektin yang berbentuk amorf. Oleh karena itu, diperlukan modifikasi pati dari batang kelapa sawit untuk meningkatkan kadar amilosa.

Penelitian mengenai modifikasi pati batang kelapa sawit dengan menggunakan pelarut asetat pada $\mathrm{pH} 7$ sebagai bahan baku bioplastik belum pernah dilakukan, penelitian mengenai pembuatan bioplastik dari kelapa sawit sebagian besar menggunakan selulosa dan ester selulosa dari kelapa sawit (Isroi et al. 2017); (Herawan et al. 2018). Penelitian modifikasi pati kelapa sawit yang sudah dilakuan yaitu modifikasi pati kelapa sawit menggunakan phosphorus oxychloride $\left(\mathrm{POCl}_{3}\right)$ dalam larutan alkali (Haryadi, Hidayat, and Kuswanto 1996), sedangkan modifikasi secara hidrolisis menggunakan pelarut asetat belum pernah dilakukan.

Tujuan penelitian ini adalah meningkatkan sifat kimia (kadar amilosa) dan 
termal pati batang kelapa sawit melalui proses modifikasi sebagai bahan baku bioplastik. Pada penelitian ini pati dihasilkan dari proses ekstraksi batang kelapa sawit, kemudian dilakukan proses modifikasi menggunakan larutan asetat $\left(\mathrm{CH}_{3} \mathrm{COOH}+\mathrm{CH}_{3} \mathrm{COONa}\right) \quad \mathrm{pH} \quad 7$ untuk memperbaiki sifat pati yang akan digunakan sebagai bahan baku bioplastik. Penelitian ini menggunakan asam asetat dan natrium asetat untuk modifikasi karena kedua senyawa tersebut yang aman, ramah lingkungan, murah, dan mudah didapat, dimana bioplastik yang akan dihasilkan akan diaplikasikan pada produk pangan.

\section{BAHAN DAN METODE}

\section{Bahan}

Bahan yang digunakan pada penelitian ini antara lain pati batang kelapa sawit, natrium asetat teknis yang diperoleh dari PT Trijaya, asam asetat dan akuades diperoleh dari Merck. Batang kelapa sawit yang diekstraksi berasal dari perkebunan kelapa sawit di Jasinga, Bogor, Jawa Barat yang berumur 25 tahun.

\section{Metode \\ Ekstraksi Pati Batang Kelapa Sawit}

Proses ekstraksi pati dari batang kelapa sawit diawali dengan pemisahan antara batang kelapa sawit dan kulit kerasnya. Empulur yang didapat diserut hingga menjadi serbuk atau bubuk kayu. Sebelum dilakukan proses ekstraksi lebih lanjut, dilakukan uji kandungan pati dengan penambahan air, diremas dan disaring selanjutnya diendapkan pada erlenmeyer $250 \mathrm{ml}$. Jika terkandung pati, proses ekstraksi dilanjutkan. Serbuk kayu dari empulur ditambahkan air kemudian diendapkan dan disaring menggunakan kain saring sehingga terpisah antara pati dan ampas. Air yang mengandung pati diendapkan selama 3 jam sehingga didapatkan pati basah. Pati basah tersebut dicuci dengan ditambahkan air dan diendapkan selama 3 jam, kemudian dikeringkan dengan di dalam oven pada suhu $50{ }^{\circ} \mathrm{C}$ sampai kadar pati menjadi kurang lebih $10 \%$. Pati kemudian diayak menggunakan ayakan 140 mesh sehingga didapat pati batang kelapa sawit yang halus dan kering (Matondang, Wirjosentono, and Yunus 2013). Kadar pati diuji sesuai dengan SNI 01-2891-1992, butir 9 .

\section{Modifikasi Pati Batang Kelapa Sawit}

Modifikasi pati dilakukan menggunakan larutan asetat $\left(\mathrm{CH}_{3} \mathrm{COOH}+\mathrm{CH}_{3} \mathrm{COONa}\right) \mathrm{pH} 7$. Pembuatan larutan asetat $\left(\mathrm{CH}_{3} \mathrm{COOH}+\mathrm{CH}_{3} \mathrm{COONa}\right) \quad \mathrm{pH} \quad 7$ dilakukan dengan cara natrium asetat sebanyak 44,52 g dilarutkan ke dalam $50 \mathrm{ml}$ akuades, kemudian diaduk sampai natrium asetat larut sempurna. Setelah larut, ditambahkan asam asetat sedikit demi sedikit sampai mencapai $\mathrm{pH} 7$ dan ditera menggunakan akuades sampai dengan volume $1 \mathrm{I}$.

Modifikasi pati dilakukan dengan cara sebagai berikut pati batang kelapa sawit sebanyak $100 \mathrm{~g}$ dilarutkan ke dalam larutan buffer asetat pH 7 sebanyak $200 \mathrm{ml}$ di dalam beaker glass, kemudian diaduk dan dipanaskan di atas hot plate stirrer pada suhu $40{ }^{\circ} \mathrm{C}$ sampai mengental, setelah itu dikeringkan pada suhu ruang. Setelah kering, pati termodifikasi dihaluskan dan diayak 80 mesh. Pati hasil modifikasi kemudian dikarakterisasi.

\section{Karakterisasi Pati Batang Sawit}

Karakterisasi pati batang sawit meliputi komposisi kimia (kadar air, abu, protein, lemak, amilosa, dan amilopektin), gugus fungsi dengan menggunakan Fourier Transform Infra-Red (FTIR) Nicolet iS5, Thermal Gravimetry Analysis (TGA) dan Derivative Thermal Gravimetry analisis dengan menggunakan TGA Perkin Elmer 4000, serta Differential Scanning Calorimetry (DSC) analisis menggunakan 4000 Pyris 1 Perkin Elmer.

\section{HASIL DAN PEMBAHASAN}

\section{Ekstraksi Pati Batang Kelapa Sawit}

Pada proses ekstraksi pati batang kelapa sawit diperoleh pati dengan rendemen sebesar $1,2 \%$ berat kering dalam 1 batang kelapa sawit setinggi $10 \mathrm{~m}$ dan diameter $50 \mathrm{~cm}$, dan dengan kadar pati sebesar $67 \%$. Pohon kelapa sawit ditebang $1 \mathrm{~m}$ sampai dengan $2 \mathrm{~m}$ dari pucuk batang, hal ini dikarenakan batang sawit pada bagian atas mempunyai struktur serat kurang padat, semakin ke atas meninggi dan semakin ke dalam arah diameter lingkar batang sawit, maka kadar air dan kadar parenkim semakin tinggi. Pati batang kelapa sawit tersimpan dalam sel-sel Parenkim dari jaringan vascular kasar (Ridwansyah et al. 2010).

\section{Karakterisasi Pati Batang Sawit}

Karakterisasi pati meliputi komposisi kimia (kadar air, abu, protein, lemak, amilopektin, dan amilosa), gugus fungsi, weight loss, derivative weight, heat flow pati alami dan pati termodifikasi. Komposisi kimia pati batang kelapa sawit alami dan pati termodifikasi disajikan pada Tabel 1.

Dari Tabel 1 menunjukkan bahwa pada pati termodifikasi kadar air lebih rendah, kadar abu lebih tinggi, kadar protein lebih tinggi, kadar lemak lebih tinggi, kadar amilopektin lebih rendah, dan kadar amilosa lebih tinggi dibandingkan dengan pati batang kelapa sawit alami. Kandungan abu yang tinggi pada pati batang kelapa sawit disebabkan karena kandungan silika pada batang kelapa sawit tinggi (Ridwansyah et al. 2010). Kadar amilosa 
dan amilopektin pada pati batang kelapa sawit akan berpengaruh terhadap sifat fisik dan karakteristik dari bioplastik yang akan dihasilkan. Amilosa yang tinggi akan membentuk kristal yang menghasilkan sifat mekanis bioplastik yang lebih kuat dibandingkan amilopektin yang berbentuk amorf. Amilopektin akan mengakibatkan bioplastik yang dihasilkan lebih porous dan rapuh (Kamsiati, Herawati, and Purwani 2017). Pada Tabel 1 terlihat adanya peningkatan kadar amilosa pada pati termodifikasi dari $26 \%$ menjadi $29 \%$.

Hasil analisis gugus fungsi pati komersial (benchmark starch), pati alami (starch), dan pati termodifikasi (modified starch) menggunakan FTIR disajikan pada Gambar 1, hasil analisis
TGA pada Gambar 2, hasil analisis DTG pada Gambar 3, dan hasil analisis DSC pada Gambar 4.

Pada Gambar 1 menunjukkan bahwa modifikasi pati telah berhasil dilakukan ditandai dengan munculnya puncak baru $1560 \mathrm{~cm}^{-1}$ yang merupakan serapan dari bilangan gelombang gugus RCOO- (Jiang et al. 2016); (Zhang et al. 2011); (Zhigang, Linrong, and Meina 2017). Gugus RCOO- menandakan asam asetat telah menghidrolisis ikatan glikosidik (COC) pada pati. Asam asetat $\left(\mathrm{CH}_{3} \mathrm{COOH}\right)$ berfungsi untuk menghidrolisis pati yang bercabang (amilopektin) menjadi rantai-rantai pati yang lurus (seperti amilosa).

Tabel 1. Komposisi kimia pati batang kelapa sawit alami dan termodifikasi

\begin{tabular}{llll}
\hline Analisis kimia (\%) & Pati alami & Pati termodifikasi & Metode uji \\
\hline Kadar Air & 31,83 & 11,01 & Gravimetri \\
Kadar Abu & 0,80 & 4,59 & Gravimetri \\
Kadar Protein & 0,59 & 0,77 & Spektrofotometri \\
Kadar Lemak & 0,36 & 0,56 & Spektrofotometri \\
Kadar Amilopektin & 40,40 & 34,10 & Perhitungan \\
Kadar Amilosa & 26,00 & 29,00 & Spektrofotometri \\
\hline
\end{tabular}

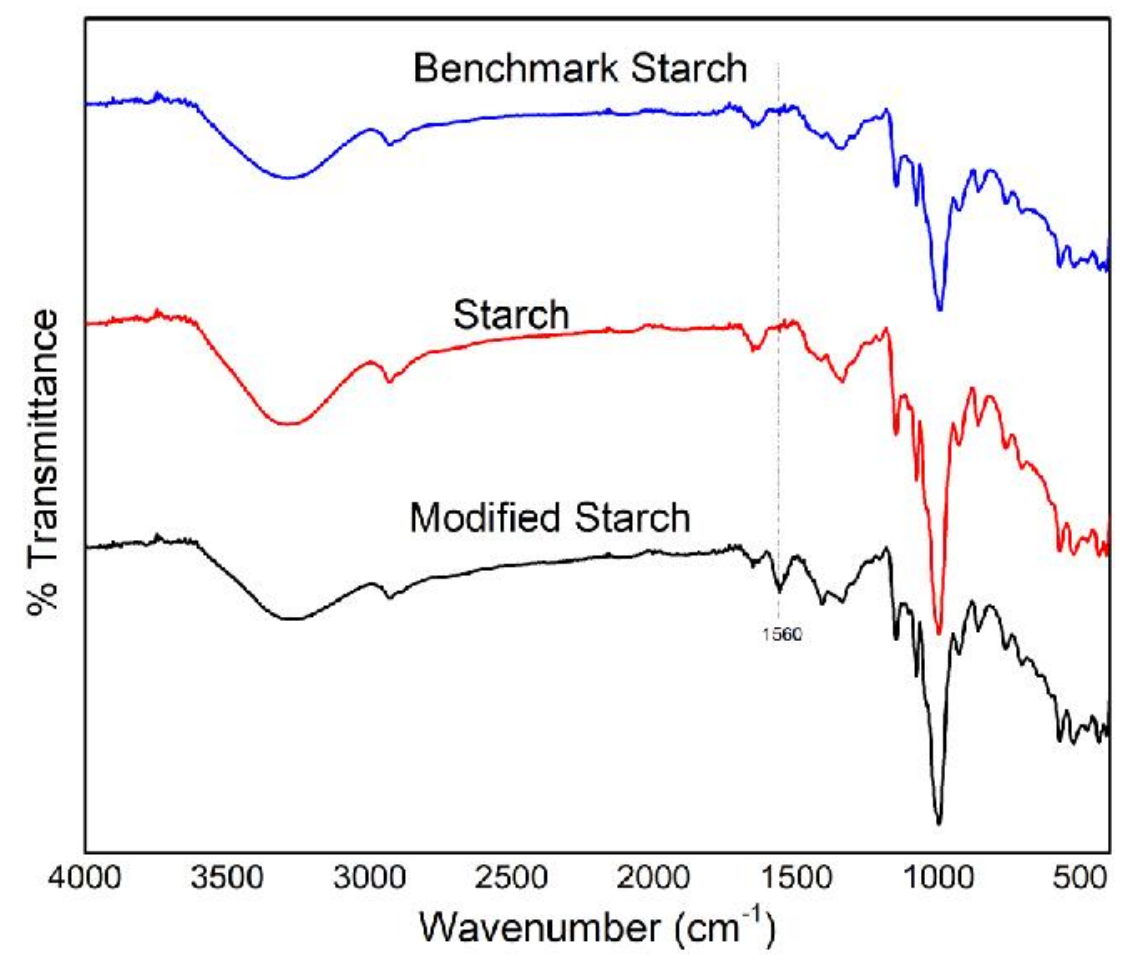

Gambar 1. Hasil analisis gugus fungsi pati alami (starch), pati komersil (benchmark starch), dan pati termodifikasi (modified starch) 
Hasil analisis TGA (Gambar 2) menunjukkan bahwa pati batang kelapa sawit termodifikasi menunjukkan lebih cepat terdegradasi dibandingkan pati batang kelapa sawit tidak termodifikasi/alami. Hal ini membuktikan bahwa modifikasi asam telah menghidrolisis pati menghasilkan rantai-rantai lurus yang lebih banyak. Tetapi setelah suhu $350{ }^{\circ} \mathrm{C}$, terjadi peningkatan kestabilan dari pati termodifikasi (biru). Hal ini sesuai literatur bahwa pati yang terasetilasi akan meningkatkan kestabilan dari pati, ini dikarenakan berkurangnya jumlah gugus $\mathrm{OH}$ setelah asetilasi (Colussi et al. 2014). Data DTG (Gambar 3) juga menunjukkan bahwa pengurangan massa pati termodifikasi (biru) lebih kecil dari pati batang kelapa sawit tidak termodifikasi/alami. Dari data DTG (Gambar 3) juga terdapat puncak disekitar $40{ }^{\circ} \mathrm{C}$ sampai dengan $120^{\circ} \mathrm{C}$ yang merupakan degradasi dari molekul air yang juga berkolerasi terhadap jumlah air pada setiap sampel
(Thitisomboon et al. 2018). Dari puncak tersebut, terlihat bahwa jumlah air pada pati termodifikasi lebih sedikit dibandingkan pati lainnya. Hal ini ditandai dengan puncak pati termodifikasi (biru) yang lebih kecil dibandingkan dengan pati tidak termodifikasi. Hal ini dikarenakan berkurangnya gugus $\mathrm{OH}$ setelah asetilasi juga mengurangi ikatan hidrogen yang mungkin terjadi antara gugus $\mathrm{OH}$ pada sampel pati dengan molekul air.

Data DSC (Gambar 4) menunjukkan bahwa pati batang kelapa sawit termodifikasi mempunyai $\mathrm{Tg}$ (Gelatinization Temperature) yang lebih rendah. Hal ini terjadi karena hidrolisis rantai cabang dan asetilasi pada rantai pati menyebabkan destabilisasi struktur granular double helix amilopektin (Colussi et al. 2014), sehingga menyebabkan nilai Tg nya turun. Suhu gelatinisasi berpengaruh nyata terhadap karakteristik bioplastik pada analisis persen pengembangan volume dan biodegradasi (Dewi, Admadi, and Hartiati 2017).

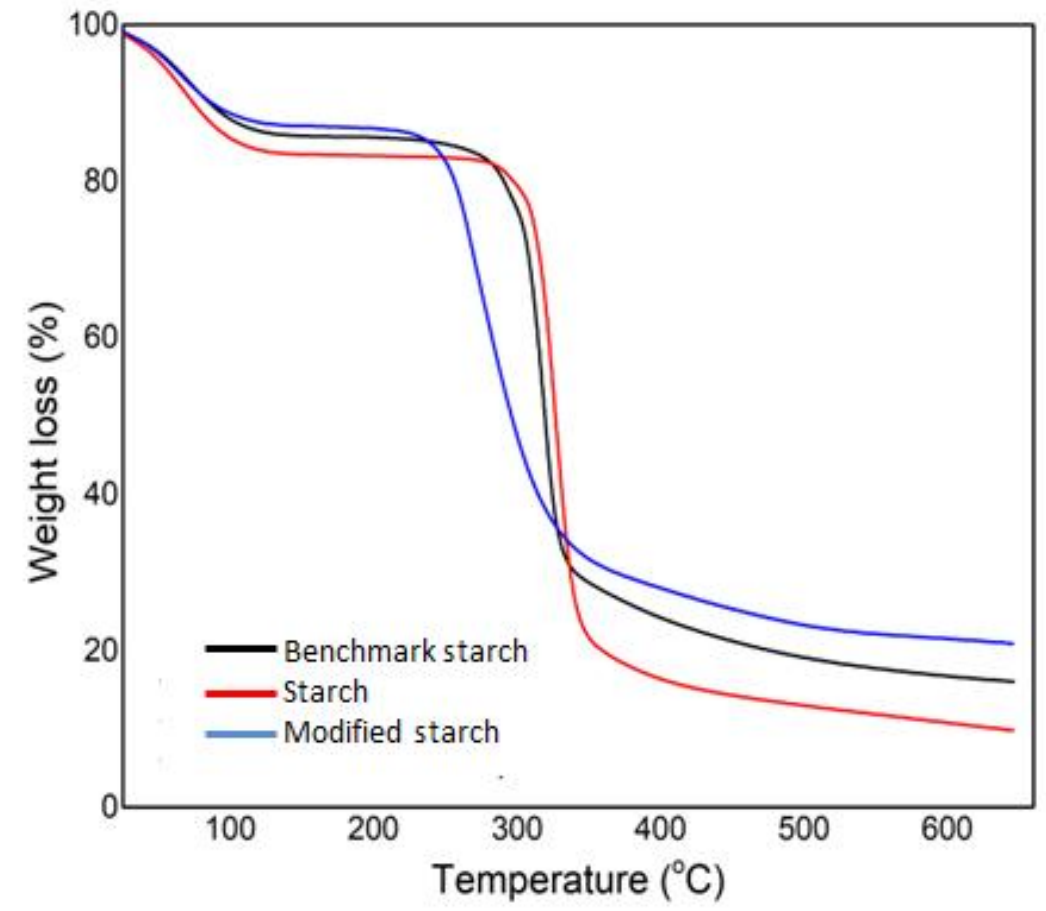

Gambar 2. Hasil analisis Thermal Gravimetry Analysis (TGA) pati alami (starch), pati komersil (benchmark starch), dan pati termodifikasi (modified starch) 


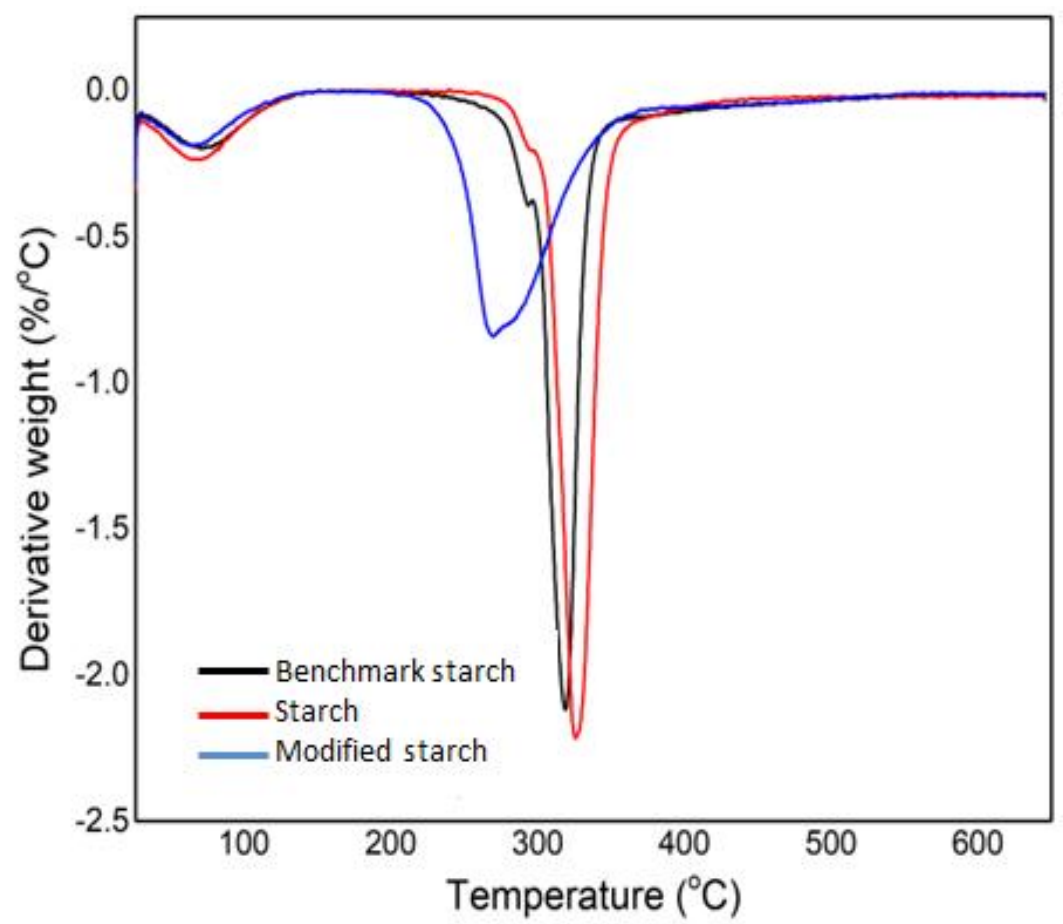

Gambar 3. Hasil analisis derivative thermal gravimetry pati alami (starch), pati komersil (benchmark starch), dan pati termodifikasi (modified starch)

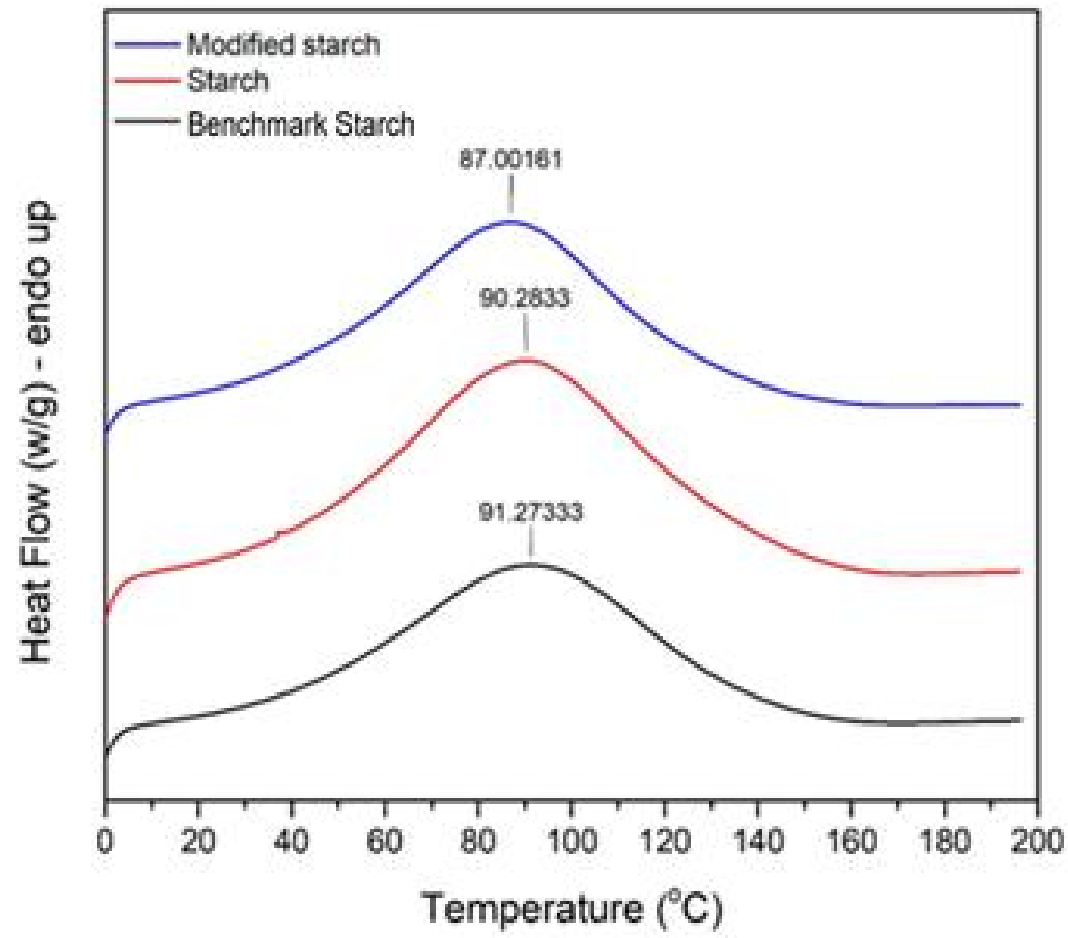

Gambar 4. Hasil analisis Differential Scaning Calorimetry (DSC) pati alami (starch), pati komersil (benchmark starch), dan pati termodifikasi (modified starch)

\section{KESIMPULAN}

Ekstraksi dalam 1 batang kelapa sawit setinggi $10 \mathrm{~m}$ dan diameter $50 \mathrm{~cm}$, dengan kadar pati sebesar $67 \%$. Peningkatan kadar amilosa dan hasil analisis TGA yang menunjukkan pati batang 
kelapa sawit termodifikasi mudah terdegradasi, mengindikasikan pati batang kelapa sawit termodifikasi baik diaplikasikan sebagai bahan baku bioplastik sebagai alternatif pengganti plastik. Amilosa yang tinggi menghasilkan sifat mekanis bioplastik yang lebih kuat dibandingkan dengan bioplastik menggunakan pati batang kelapa sawit alami.

\section{DAFTAR PUSTAKA}

Aripin, S., B. Saing, and E. Kustiyah. 2017. "Studi Pembuatan Bahan Alternatif Plastik Biodegradable Dari Pati Ubi Jalar Dengan Plasticizer Gliserol Dengan Metode Melt Intercalation." Jurnal Teknik Mesin 06: 7984.

Colussi, R., V. Z. Pinto, S. L. M. El Halal, N. L. Vanier, F. A. Villanova, R. Marques e Silva, E. da Rosa Zavareze, and A. R. G. Dias. 2014. "Structural, Morphological, and Physicochemical Properties of Acetylated High-, Medium-, and LowAmylose Rice Starches." Carbohydrate Polymers 103 (2014): 405-13. https://doi.org/10.1016/J.CARBPOL.2013. 12.070 .

Coniwanti, P., L. Laila, and M. R. Alfira. 2014. "Pembuatan Film Plastik Biodegredabel Dari Pati Jagung Dengan Penambahan Kitosan Dan Pemplastis Gliserol." Jurnal Teknik Kimia UNSRI 20 (4): 22-30.

Cornelia, M., R. Syarief, H. Effendi, and B. Nurtama. 2013. "Pemanfaatan Pati Biji Durian (Durio Zibethinus Murr.) Dan Pati Sagu (Metroxylon Sp.) Dalam Pembuatan Bioplastik." Jurnal Kimia Dan Kemasan 35 (1): 20-29.

Darni, Y., and H. Utami. 2010. "Studi Pembuatan Dan Karakteristik Sifat Mekanik Dan Hidrofobisitas Bioplastik Dari Pati Sorgum." Jurnal Rekayasa Kimia Dan Lingkungan 7 (4): 88-93. https://doi.org/10.1038/srep39734.

Dewi, N. L. G. S, B. Admadi, and A. Hartiati. 2017. "Karakteristik Bioplastik Alginat Dari Rumput Laut Ulva Lactuca (Tinjauan Suhu Dan Lama Gelatinisasi)." Jurnal Rekayasa Dan Manajemen Agroindustri 5 (3): 6673.

Erika, C. 2010. "Produksi Pati Termodifikasi Dari Beberapa Jenis Pati." Jurnal Rekayasa Kimia Dan Lingkungan 7 (3): 130-37.

Harsojuwono, B. A., I. W. Arnata, and S. Mulyani. 2017. "Biodegradable Plastic Characteristics of Cassava Starch Modified in Variations Temperature and Drying Time." Chemical and Process Engineering Research 49: 1-5.

Haryadi, H., C. Hidayat, and K. R. Kuswanto. 1996. "Characteristics of Cross Linked Oil Palm Starch." Indonesian Food and
Nutrition Progress 3 (2): 57-60.

Herawan, T., M. Rivani, H. Halimatudahliana, and S. Irawan. 2018. "Oil Palm Based Cellulose Esters as Raw Material for Environmentally Friendly Bio-Plastic." Majalah Kulit, Karet Dan Plastik 34 (1): 33-40.

Isroi, I., A. Cifriadi, T. Panji, N. A. Wibowo, and K. Syamsu. 2017. "Bioplastic Production from Cellulose of Oil Palm Empty Fruit Bunch." In IOP Conf. Series: Earth and Environmental Science 65.

Jiang, S., L. Dai, Y. Qin, L. Xiong, and Q. Sun. 2016. "Preparation and Characterization of Octenyl Succinic Anhydride Modified Taro Starch Nanoparticles." PLOS ONE 11 (2): $1-11$. https://doi.org/10.1371/journal.pone.01500 43.

Kamsiati, E., H. Herawati, and E. Y. Purwani. 2017. "Potensi Pengembangan Plastik Biodegradable Berbasis Pati Sagu Dan Ubikayu Di Indonesia." Jurnal Penelitian Dan Pengembangan Pertanian 36 (2): 6776.

https://doi.org/10.21082/jp3.v36n2.2017.p 67-76.

Korma, S. A., K. Alahmad, S. Niazi, A. F. Ammar, F. Zaaboul, and T. Zhang. 2016. "Chemically Modified Starch and Utilization in Food Stuffs." International Journal of Nutrition and Food Sciences 5 (4): $\quad$ 264-72. https://doi.org/10.11648/j.jjnfs.20160504.1 5.

Matondang, T. D. S., B. Wirjosentono, and D. Yunus. 2013. "Pembuatan Plastik Kemasan Terbiodegradasikan Dari Polipropylena Tergrafting Maleat Anhidrida Dengan Bahan Pengisi Pati Sagu Kelapa Sawit." Jurnal Kimia Valensi $3(2): 110-16$.

Onyango, C. 2016. "Starch and Modified Starch in Bread Making: A Review." African Journal of Food Science 10 (12): 344-51. https://doi.org/10.5897/AJFS2016.1481.

Purbasari, A., E. F. Ariani, and R. K. Mediani. 2014. "Bioplastik Dari Tepung Dan Pati Biji Nangka." Prosiding SNST Fakultas Teknik Universitas Wahid Hasyim Semarang 34: 54-59.

Ridwansyah, R., M. Z. Nasution, T. C. Sunarti, and A. M. Fauzi. 2010. "Karakteristik Sifat Fisiko-Kimia Pati Kelapa Sawit." J. Tek. Ind. Pert. 17 (1): 1-6.

Saputro, A. N. C, and A. L. Ovita. 2017. "Sintesis Dan Karakterisasi Bioplastik Dari KitosanPati Ganyong (Canna Edulis)." Kimia Dan Pendidikan Kimia 2 (1): 13-21. https://doi.org/10.1017/S1355770X150000 17.

Silviana, S., and P. Rahayu. 2017. "Pembuatan 
Bioplastik Berbahan Pati Sagu Dengan Penguat Mikrofibril Selulosa Bambu Terdispersi KCl Melalui Proses Sonikasi." $\begin{array}{llll}\text { Reaktor } & 17 & \text { (3): } & 151-56 .\end{array}$ https://doi.org/10.1126/scitranslmed.3001 669.

Supeni, G., A. A. Cahyaningtyas, and A. Fitrina. 2015. "Karakterisasi Sifat Fisik Dan Mekanik Penambahan Kitosan Pada Edible Film Karagenan Dan Tapioka Termodifikasi." Jurnal Kimia Dan Kemasan 37 (2): 103-10.

Suryanto, H., N. E. Wahyuningtyas, R. Wanjaya, P. Puspitasari, and S Sukarni. 2016. "Struktur Dan Kekerasan Bioplastik Dari Pati Singkong." Proceeding Seminar Nasional SenTerTek, Polinema Malang, no. November: 1-6.

Thitisomboon, Wadeelada, Pakorn Opaprakasit, Narisara Jaikaew, and Siwarutt Boonyarattanakalin. 2018. "Characterizations of Modified Cassava Starch with Long Chain Fatty Acid Chlorides Obtained from Esterification under Low Reaction Temperature and Its PLA Blending." Journal of Macromolecular Science, Part A: Pure and Applied
Chemistry $55 \quad$ (3): $253-59$. https://doi.org/10.1080/10601325.2018.14 24551.

Yuliasih, I., and T. C. Sunarti. 2014. "Pati Sagu Termodifikasi Sebagai Bahan StarchBased Plastics." In Prosiding Seminar Nasional Kulit, Karet, Dan Plastik, 3:6783.

Zhang, B., Q. Huang, F. Luo, X. Fu, H. Jiang, and J. Jane. 2011. "Effects of Octenylsuccinylation on the Structure and Properties of High-Amylose Maize Starch." Carbohydrate Polymers 84 (4): 1276-81. https://doi.org/10.1016/J.CARBPOL.2011. 01.020.

Zhigang, L., S. Linrong, and Z. Meina. 2017. "Formulation Science \& Bioavailability Preparation of Starch Nanoparticles in a New Ionic Liquid-in-Oil Micro- Emulsion." Journal of Formulation Science \& Bioavailability 1 (1): 1-8.

Zulaidah, A. 2012. "Peningkatan Nilai Guna Pati Alami Melalui Proses Modifikasi Pati." Dinamika Sains 10 (22): 1-13. https://doi.org/10.1111/ane.12608. 